\title{
Effects of cholesterol and Lactobacillus acidophilus on testicular function
}

\author{
Gülay Çiftci, Elif Tuna \\ Department of Biochemistry, Faculty of Veterinary Medicine, University of Ondokuz Mayis, Samsun, Turkey
}

Objective: In this study, the effects of Lactobacillus acidophilus on testosterone (TES), follicle-stimulating hormone (FSH), luteinizing hormone (LH), androgen-binding protein (ABP), factor-associated apoptosis (FAS), and total cholesterol (TC), as well as histopathological changes, were investigated in male rats fed a high-cholesterol diet.

Methods: The study included three groups. The control (C) group was fed standard-diet for 8 weeks. The hypercholesterolemia (HC) group was fed a $2 \%$ cholesterol-diet for 8 weeks. The therapeutic group (HCL) was fed a 2\% cholesterol-diet for 8 weeks and administered L. acidophilus for the last 4 weeks. FSH, TES, and FAS levels in testicular tissue were determined using an enzyme-linked immunosorbent assay (ELISA), while another sample was examined histopathologically. LH and ABP levels were determined using ELISA, and serum TC levels were assessed via an autoanalyzer.

Results: In the HC group, the TC levels were significantly higher and the LH levels were lower $(p<0.05)$ than in the C group. The ABP levels were lower $(p>0.05)$. In the HCL group, the LH and ABP levels were higher $(p>0.05)$ and the TC level significantly lower $(p<0.05)$ than in the HC group. The TES and FSH levels were lower, and the FAS levels were higher, in the HC than in the C group $(p<0.05)$. In the HCL group, levels of all three resembled control levels. Histologically, in the testicular tissue of the $\mathrm{HC}$ group, the cells in the tubular wall exhibited atrophy, vacuolization, and reduced wall structure integrity. However, in the $\mathrm{HCL}$ group, these deteriorations were largely reversed.

Conclusion: Supplementary dietary administration of an L. acidophilus to hypercholesterolemic male rats positively impacted testicular tissue and male fertility hormone levels.

Keywords: Hypercholesterolemia; Lactobacillus acidophilus; Testicular function

\section{Introduction}

Cholesterol is a sterol biosynthesized in all animal cells due to its structural role in animal cell membranes [1]. In addition, cholesterol is a precursor to the biosynthesis of steroid hormones, bile acids, and vitamin D [2]. Most cholesterol synthesis takes place in the liver, although some occurs in the kidneys, intestines, and adrenal glands

Received: December 12, 2020 · Revised: April 12, 2021 · Accepted: May 17, 2021 Corresponding author: Gülay Ciftci

Department of Biochemistry, Faculty of Veterinary Medicine, University of Ondokuz Mayis, 55220 Atakum, Samsun, Turkey

Tel: +90-50-5615-0074 Fax: +90-362-457-6922 E-mail: gciftci@omu.edu.tr

*This research was supported by the Scientific Research Projects Commission of Ondokuz Mayis University (Contract Grand No. PYO-VET.1904.16.019).

This is an Open Access article distributed under the terms of the Creative Commons Attribution Non-Commercial License (http://creativecommons.org/licenses/by-nc/4.0/) which permits unrestricted non-commercial use, distribution, and reproduction in any medium, provided the original work is properly cited.
[3]. Hypercholesterolemia is associated with male reproductive dysfunction. For example, a high-cholesterol diet in male rats is associated with decreases in sperm quality and in the nuclear dimensions of Leydig cells, both of which lead to infertility $[4,5]$.

Probiotics are live microbial food additives that have beneficial effects on host health by regulating the microbial balance of the intestinal tract. The most widely used probiotic microorganisms are $\mathrm{Bi}$ fidobacterium and Lactobacillus species. Lactic acid bacteria cultures, especially dairy products containing Lactobacillus acidophilus, have been found to lower serum cholesterol and increase the quantity of fecal Lactobacilli [6].

Differing opinions exist regarding the mechanism of the serum cholesterol-lowering effects of probiotic bacteria. The most common belief is that probiotics are rapidly eliminated from the intestinal tract by breaking down bile salts into free acids. The synthesis of bile acids from cholesterol decreases the overall concentration of cholesterol in the body, as free bile salts are excreted from the body [7]. 
Globally, hypercholesterolemia is a very common health issue. In this study, we investigated the addition of the probiotic L. acidophilus to male rats fed a high-cholesterol diet. We aimed to investigate the histopathological impact on testicular tissue along with the effects on testosterone (TES), follicle-stimulating hormone (FSH), luteinizing hormone (LH), androgen-binding protein (ABP), and apoptosis.

\section{Methods}

\section{Animal materials}

Twenty-four male Sprague-Dawley rats 10-12 weeks of age and weighing 300-350 g were used in this study. The rats were obtained from Ondokuz Mayis University Experimental Animals Application and Research Center. The present study was conducted with the permission of the Ondokuz Mayıs University Animal Experiments Local Ethics Committee (2016/27). During the study, an environment with a room temperature of $22^{\circ} \mathrm{C} \pm 2^{\circ} \mathrm{C}, 60 \%$ humidity, and a $12 / 12$ hour light/dark cycle was provided. The experimental animals were fed ad libitum throughout the study.

\section{Preparation of probiotic suspensions}

Lyophilized L. acidophilus ATCC 4356 was supplied for use as a probiotic medication. The bacteria were inoculated with de Man, Rogosa, and Sharpe (MRS) agar for viability, and the purity was confirmed by diluting the lyophilized bacteria with MRS broth. One milliliter of the culture, determined to be viable and pure, was added to $500 \mathrm{~mL}$ of MRS agar and incubated at $35^{\circ} \mathrm{C}$ for 48 hours. At the end of the incubation period, the suspension was inoculated to MRS agar plates and incubated at $35^{\circ} \mathrm{C}$ for 48 hours. After incubation, the bacterial colonies were counted, and the concentration of bacteria (colony-forming units $[\mathrm{CFU}] / \mathrm{mL}$ ) in the main culture was calculated. Then, $10^{10} \mathrm{CFU} / \mathrm{mL}$ bacteria were suspended in the main culture, and a probiotic suspension of L. acidophilus was prepared for use as treatment [8].

\section{Animal experiment}

For the animal experiment, three groups of eight rats were established. (1) Group 1 ( $n=8$, control group [C]): the animals of the control group were fed standard rat food ad libitum for 8 weeks. (2) Group 2 ( $n=8,2 \%$ cholesterol $[H C])$ : this group was fed standard rat food with 2\% cholesterol ad libitum for 8 weeks $[9,10]$. (3) Group 3 ( $2 \%$ cholesterol + L. acidophilus $[\mathrm{HCL}])$ : this group was fed standard rat food with $2 \%$ cholesterol ad libitum for 8 weeks $[9,10]$. For the last 4 weeks of the experiment, L. acidophilus probiotic $\left(2 \times 10^{8} \mathrm{CFU} /\right.$ $\mathrm{mL} /$ day) was administered via oral gavage [8].

At the end of the study, the rats were individually weighed, and 10\% ketamine (Ketasol; Richter Pharma Ag, Wels, Austria; 0.8-1.3 $\mathrm{mL} / \mathrm{kg}$ ) and 2\% xylazine (Basilazine; Bavet, Istanbul, Turkey; 2-5 mg/ $\mathrm{kg}$ ) were applied via intraperitoneal injection. Each rat was decapitated after the blood was drained from the heart, and testicular tissue samples were taken after necropsy.

\section{Preparation of testicular tissue samples for enzyme-linked immunosorbent assay}

The testicular tissue samples were weighed after washing with ice-cold phosphate-buffered saline $(0.01 \mathrm{~mol} / \mathrm{L}, \mathrm{pH} 7.0-7.2)$ before homogenization. After the tissue was divided into small pieces, homogenization was performed in 5-10 $\mathrm{mL}$ phosphate buffer solution with an ice homogenizer. The cell membrane was subsequently broken down twice with ice ultrasonics, and ice cream thawing was applied twice for better cell disintegration. The homogenates were centrifuged at $5,000 \times g\left(4^{\circ} \mathrm{C}\right)$ for 5 minutes. They were then divided into supernatant aliquots and stored at $-80^{\circ} \mathrm{C}$ until the analyses were performed.

\section{Determination of testicular TES, FSH, and factor-associated apoptosis levels using enzyme-linked immunosorbent assay}

Specific enzyme-linked immunosorbent assay (ELISA) kits were used to assess the levels of TES, FSH, and factor-associated apoptosis (FAS) in the testicular tissue supernatants of each rat. The ELISA procedures were performed according to the manufacturer's instructions, and the absorbance levels (as optical density values) of the ELISA plates were measured with an ELISA reader.

\section{Determination of serum biochemical parameters}

The $L H$ and $A B P$ levels of each rat were determined using specific ELISA kits. The ELISA procedures were performed according to the manufacturer's instructions, and the absorbance levels (as optical density values) of the ELISA plates were measured with an ELISA reader. Serum TAC levels were measured spectrophotometrically with an autoanalyzer. For this analysis, appropriate quantities of the samples and reagents were mixed with standard solutions. The results of the analyses were calculated using optical reading at a specific time and temperature.

\section{Histopathological examination of testicular tissues}

For the histopathological examination, the testicles of the rats were removed and cleaned from the surrounding tissues. The testicles were fixed in a $10 \%$ formaldehyde solution for histological examination. The tissues were subjected to routine histopathological follow-up procedures after the detection process and blocked with paraffin. From the resulting paraffin blocks, $5-\mu \mathrm{m}$ sections were taken using a Leica RM2235 microtome (Leica Biosystems, Wetzlar, Germany). To analyze the complex histological structure of the testicles, the Crossmon triple staining technique was applied to the sections. The 
stained preparations were examined and photographed in detail with a Nikon Eclipse 50i research microscope (Nikon, Tokyo, Japan).

\section{Statistical analysis}

SPSS ver. 16.0 (SPSS Inc., Chicago, USA, USA) was used for statistical analysis. One-way analysis of variance, Duncan multiple range, and Pearson correlation tests were used to evaluate the differences and relationships among the groups.

\section{Results}

\section{Determination of TES, FSH, and FAS levels using ELISA}

The levels of FSH, FSH, and FAS in the extracted testicular tissue supernatants are presented in Table 1 as mean \pm standard error (SE). The average TES levels in the $\mathrm{C}, \mathrm{HC}$, and $\mathrm{HCL}$ groups were $172.34 \pm 3.86$, $121.75 \pm 8.82$, and $170.61 \pm 6.59$ (ng/mg tissue), respectively. The mean TES level in the testicular tissue was significantly lower in the $\mathrm{HC}$ group than in the $\mathrm{C}$ group, while the level was higher in the $\mathrm{HCL}$ group than in the $\mathrm{HC}$ group.

The FSH levels of the C, HC, and HCL groups were 129.41 \pm 1.43 , $115.47 \pm 4.67$, and $125.08 \pm 1.28 \mathrm{IU} / \mathrm{mg}$ tissue, respectively. In the HC group, the mean FSH level was dramatically lower than in the $C$ group; the level in the $\mathrm{HCL}$ group was higher than in the $\mathrm{HC}$ group and approached that of the $\mathrm{C}$ group. In the $\mathrm{C}, \mathrm{HC}$, and $\mathrm{HCL}$ groups, the FAS levels in the testicular tissues were $1.32 \pm 0.06,1.87 \pm 0.08$, and $1.51 \pm 0.03 \mathrm{ng} / \mathrm{mg}$ tissue, respectively. The mean FAS level was

Table 1. The levels of FSH, TES, and FAS in the testicular tissue supernatants

\begin{tabular}{lrrr}
\hline Variable & \multicolumn{1}{c}{$\mathrm{C}$} & $\mathrm{HC}$ & \multicolumn{1}{c}{$\mathrm{HCL}$} \\
\hline FSH (IU/mg tissue) & $129.41 \pm 1.43^{\mathrm{a})}$ & $115.47 \pm 4.67^{\mathrm{b})}$ & $125.08 \pm 1.28^{\mathrm{a})}$ \\
TES (ng/mg tissue) & $172.34 \pm 3.86^{\mathrm{a})}$ & $121.75 \pm 8.82^{\mathrm{b})}$ & $170.61 \pm 6.59^{\mathrm{a})}$ \\
FAS (ng/mg tissue) & $1.32 \pm 0.06^{\mathrm{a})}$ & $1.87 \pm 0.08^{\mathrm{b})}$ & $1.51 \pm 0.03^{\mathrm{a})}$ \\
\hline
\end{tabular}

Values are presented as mean \pm standard error.

FSH, follicle-stimulating hormone; TES, testosterone; FAS, factor-associated apoptosis; C, control group; $\mathrm{HC}$, hypercholesterolemia group; $\mathrm{HCL}$, hypercholesterolemia+probiotic group.

a),b) Significant differences between groups are indicated by different letters in the same row $(p<0.05)$.

Table 2. The levels of $L H, A B P$, and $T C$ in the serum

\begin{tabular}{lccc}
\hline Variable & $\mathrm{C}$ & $\mathrm{HC}$ & $\mathrm{HCL}$ \\
\hline $\mathrm{LH}(\mathrm{mlU} / \mathrm{mL})$ & $12.15 \pm 0.41^{\mathrm{a})}$ & $7.77 \pm 0.15^{\mathrm{b})}$ & $7.85 \pm 0.43^{\mathrm{b})}$ \\
$\mathrm{ABP}(\mathrm{nmol} / \mathrm{L})$ & $46.74 \pm 0.76$ & $43.91 \pm 1.72$ & $47.12 \pm 0.56$ \\
$\mathrm{TC}(\mathrm{mg} / \mathrm{dL})$ & $52.25 \pm 1.75^{\mathrm{a})}$ & $75.75 \pm 1.98^{\mathrm{b})}$ & $60.95 \pm 0.84^{\mathrm{c})}$ \\
\hline
\end{tabular}

$\mathrm{LH}$, luteinizing hormone; $\mathrm{ABP}$, androgen-binding protein; $\mathrm{TC}$, total cholesterol; $\mathrm{C}$, control group; $\mathrm{HC}$, hypercholesterolemia group; $\mathrm{HCL}$, hypercholesterolemia+probiotic group.

a),b),c) Significant differences between groups are indicated by different letters in the same row $(p<0.05)$. significantly greater in the $\mathrm{HC}$ group than in the $\mathrm{C}$ and $\mathrm{HCL}$ groups.

\section{Serum biochemical parameter levels in serum}

The means and standard deviations of the serum $\mathrm{LH}, \mathrm{ABP}$, and total cholesterol (TC) levels of the $\mathrm{C}, \mathrm{HC}$, and $\mathrm{HCL}$ groups are presented in Table 2 as mean \pm SE. The $\mathrm{LH}$ levels of the $\mathrm{C}, \mathrm{HC}$, and HCL groups were $12.15 \pm 0.41,7.77 \pm 0.15$, and $7.85 \pm 0.43(\mathrm{mlU} / \mathrm{mL})$, respectively. The $\mathrm{LH}$ levels were lower in the $\mathrm{HC}$ and $\mathrm{HCL}$ groups than in the $\mathrm{C}$ group ( $p>0.05$ ). The ABP levels of the $\mathrm{C}, \mathrm{HC}$, and $\mathrm{HCL}$ groups were $46.74 \pm 0.76,43.91 \pm 1.72$, and $47.12 \pm 0.56(\mathrm{nmol} / \mathrm{L})$, respectively. Relative to the control, the ABP level was slightly higher in the $\mathrm{HCL}$ group and lower in the HC group $(p>0.05)$. The TC levels of the $C$, $\mathrm{HC}$, and $\mathrm{HCL}$ groups were $52.25 \pm 1.75,75.75 \pm 1.98$, and $60.95 \pm 0.84$ $\mathrm{mg} / \mathrm{dL}$, respectively. The TC levels were greater in the $\mathrm{HCL}$ and $\mathrm{HC}$ groups than in the $\mathrm{C}$ group.

\section{Correlations}

Correlations between groups with respect to TES, ABP, LH, TC, FSH, and FAS levels are presented in Table 3 as mean \pm SE. The results included a significant negative correlation between $\mathrm{TC}$ and $\mathrm{LH}$ levels $(r=-0.711, p<0.01)$, a negative correlation between ABP and TC levels $(r=-0.282)$, a significant positive correlation between FSH and TES levels $(r=0.535, p<0.01)$, and a significant negative correlation between FSH and TC levels $(r=-0.656, p<0.01)$. A significant negative correlation $(r=-0.723, p<0.01)$ was found between TES and TC levels. FAS level was significantly negatively correlated with $\mathrm{LH}, \mathrm{FSH}$, and TES levels ( $r=-0.548, p<0.01 ; r=-0.698, p<0.01 ; r=0.859$, $p<0.01$ ), while it was significantly positively correlated with TC level $(r=0.821, p<0.01)$.

\section{Results of the histopathological examination}

The testicular tissues were found to be surrounded by tunica albuginea, an externally irregular tight connective tissue. Seminiferous tubules of different lengths and diameters were observed in these structures, where the tunica albuginea divides the organ into sep-

Table 3. Correlation relationships among the groups

\begin{tabular}{lcccccc}
\hline Variable & LH & ABP & FSH & TES & TC & FAS \\
\hline LH & 1 & 0.129 & 0.365 & 0.343 & $-0.711^{\text {b) }}$ & $-0.548^{\text {b) }}$ \\
ABP & & 1 & 0.232 & $0.472^{\text {a) }}$ & -0.282 & -0.356 \\
FSH & & & 1 & $0.535^{\text {b) }}$ & $-0.656^{\text {b) }}$ & $-0.698^{\text {b) }}$ \\
TES & & & & 1 & $-0.723^{\text {b) }}$ & $-0.859^{\text {b) }}$ \\
TC & & & & & 1 & $0.82^{\text {b) }}$
\end{tabular}

FAS

$\mathrm{LH}$, luteinizing hormone; $\mathrm{ABP}$, androgen-binding protein; $\mathrm{FSH}$, follicle-stimulating hormone; TES, testosterone; TC, total cholesterol; FAS, factor-associated apoptosis.

${ }^{\text {a) }} p<0.05 ;{ }^{\text {b) }} p<0.01$. 
tum by sending arms inside the organ, termed the septula testis. Spermatocytes and Sertoli cells at different developmental stages were observed in the seminiferous tubules. In the loose connective tissue between the tubules, small blood vessels and Leydig cells were detected. The tubule walls of the groups were evaluated and compared. In the testicles of the HC group, atrophy, vacuolization, and decreased integrity of the wall structure were observed in the cells in the tubule wall. A significant difference was found relative to the $\mathrm{C}$ group. However, in the samples from the $\mathrm{HCL}$ group, degenerate tubule wall cells were almost nonexistent, and the wall structure was preserved (Figure 1).

\section{Discussion}

The effects of probiotics on living beings and their health benefits have been emphasized in several studies. This includes their effect on hypercholesterolemia, particularly their role in suppressing advanced cholesterol synthesis and preventing the absorption of excess cholesterol [11]. Cholesterol is essential for the body because it plays a very important role in daily life. It is a crucial component of the cell membrane, as well as bile acid synthesis, fat and fat-soluble vitamin absorption, and synthesis of steroid hormones (sex hormones, mineralocorticoids, and glucocorticoids) [12]. A high-cholesterol diet is the primary cause of hyperlipidemia, atherosclerosis, and other lipid metabolism disorders that lead to male reproductive system defects [13]. In hypercholesterolemia, erythrocytes and endothelial cells, as well as serum, increase the amount of cholesterol present. The increase in the quantity of oxidized free radical products in these cells has been reported to cause elevated cholesterol [14]. Hypercholesterolemia is currently a widespread and common health issue. Several studies have shown that beneficial bacterial additives can lower serum cholesterol levels in fermented milk products or milk products containing lactic acid bacteria [10].The therapeutic value of fermented dairy products depends on the survival of these bacteria during development and storage [15]. In the present study, a rat model of hypercholesterolemia was developed, and L. acidophilus ATCC 4356 - the lipid-lowering properties of which have been demonstrated in vitro and in vivo — was administered intragastrically $[10,16]$. The results are consistent with previous reports suggesting that $L$. acidophilus has a cholesterol-lowering effect [17-19]. Walker and Gilliland [20] posited that L. acidophilus secretes bile salt hydrolase to deconjugate bile salts, although no connection was found between the reduction of in vitro cholesterol and the degree of bile salt deconjugation [21]. These conflicting findings raise the possibility of other mechanisms that may be associated with the assimilation of cholesterol by probiotic bacteria during their development [22]. In the present study, the TC level was elevated in the $\mathrm{HC}$ and $\mathrm{HCL}$ groups $(p<0.05)$ relative to the control. Our analysis indicates that $L$. acidophilus plays a major role in cholesterol synthesis. The administration of this probiotic may result in increased catabolism of cholesterol in the liver, contributing to a hypocholesterolemic impact. Several clinical and epidemiological studies have shown an inverse association between serum TES levels and TC [23]. In addition, animal experiments in TES-deficient male mice have also shown dramatically elevated serum cholesterol levels [24,25]. Circulating TES levels are determined by the steroidogenic potential of Leydig cells and the to-
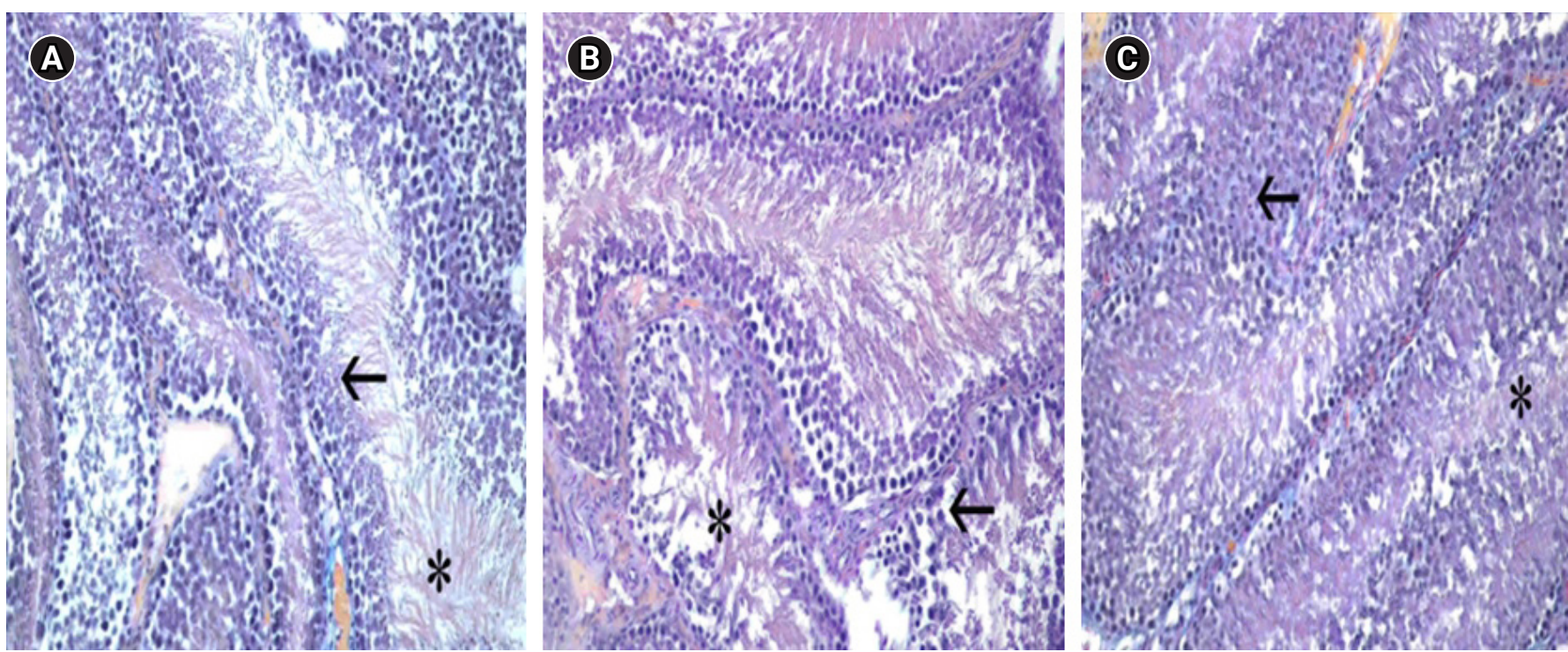

Figure 1. Rat testis tissue belonging to the control group (A), the hypercholesterolemia group (B), and the probiotic and hypercholesterolemia group (C). Arrow, spermatogenetic serial cells separated from each other in seminiferous tubules; asterisk, seminiferous lumen (H\&E; triple, $\times 20)$. 
tal number of Leydig cells per testicle. Stress-induced increases in serum glucocorticoid concentration have been reported to decrease the rate of TES release by inhibiting the activity of TES biosynthetic enzymes [26]. In another investigation of the impact of probiotics, larger testes and higher serum TES levels were observed in male mice that regularly ingested lactic acid bacteria than in age-matched control mice. Lactobacillus reuteri was administered as a probiotic in that study, and a thorough analysis with microscopy-assisted histomorphometry showed an increase in the extent of spermatogenesis and the number of Leydig cells per testis. Furthermore, gonadal aging symptoms were claimed to decrease [27]. Mega Acidophilus (a mixture of L. acidophilus, Bifidobacterium bifidum, and Lactobacillus helveticus) was administered to New Zealand rabbits for 1 month to determine how the probiotic would affect certain parameters. In that study, probiotic supplements were shown to improve antioxidant activity and substantially increase the level of TES [28]. In our study, the TES level in the group given $2 \%$ cholesterol for 8 weeks decreased in the testicular tissue, and the level of TES increased in the group given the $L$. acidophilus probiotic. Therefore, TES deficiency in the liver in $\mathrm{HC}$ does not affect de novo cholesterol synthesis. A number of human studies have shown that hypercholesterolemia and low semen quality are associated with male infertility [29-31]. Research on animals fed a high-cholesterol diet has uncovered more information about this link. In animals with diet-induced hypercholesterolemia, adverse effects of hypercholesterolemia on testicular function, including spermatogenesis, were noted [5,32-35]. Increased oxidative stress is of considerable research interest among the many pathways suggested for hypercholesterolemia-induced testicular injury [16]. When mice were fed a high-fat diet, decreased TES, decreased semen quality, seminiferous tubule atrophy, and degeneration were reported. The researchers stated that the addition of selenium-enriched probiotics to the high-fat diet decreased damage to testicular tissue and raised serum TES levels [36]. In another study, researchers examined the reproductive system structure of male rats fed a high-fat diet for 2 months. They found that sperm quality and count decreased, Leydig cell disturbances increased, spermatocyte and spermatid structures decreased, and significant narrowing of the seminiferous tubule occurred [37]. In our sample, relative to the control group, the testicles of the group given cholesterol feed (HC) showed atrophy, vacuolization, and damaged wall structure integrity in the tubule wall cells. However, in the $\mathrm{HCL}$ group, degenerate tubule wall cells were almost nonexistent, and the wall structure retained its integrity. According to recent research, high cholesterol levels caused by high-fat diets contribute to urological disorders (problems with penile erection, irregular spermatogenesis, benign enlargement of the prostate, cancer, etc.). They also disrupt the epithelial structure of the tissues and cause function- al disability [11]. The secretion of FSH and TES is required for the successful completion of spermatogenesis. TES, the male sex hormone, is secreted by Leydig cells under LH stimulation and plays important roles in the differentiation of peripheral tissues and the promotion of spermatogenesis [38,39]. ABP binds to TES and estrogens and assists their transport into the seminiferous tubule, allowing for their use for spermatozoon maturation when required [40]. Testicular ABP synthesis has been reported to be increased by FSH and TES in rats [41]. In another study, researchers investigated the impact of Lactobacillus rhamnosus PB01 on sperm kinematic parameters and found that TES, LH, and FSH levels, as well as sperm motility rates, were all significantly elevated. L. rhamnosus has also been found to act as a positive regulatory agent on weight loss and reproductive hormones [42]. In our study, serum ABP and LH levels were lower in the HC than in the control group, and the amount of FSH in the testicular tissue was also lower. ABP and $\mathrm{LH}$ levels were greater in the $\mathrm{HCL}$ group than in the $\mathrm{HC}$ group $(p>0.05)$. In parallel to our results, when a $2 \%$ cholesterol diet was given to male Wistar rats for 21 days, non-significant changes were seen in TES, LH, and prolactin levels, while the FSH level was significantly decreased [43]. In another study, a high-cholesterol diet induced a significant increase in the TC level and significant decreases in the FSH, LH, and TES levels in the serum of male rats [44]. Hypercholesterolemia has also been suggested to cause reproductive and testicular damage through excessive free radical generation and increased oxidative stress, which is cytotoxic to spermatozoa [13,34,45]. In hypercholesterolemia, the administration of antioxidants and lipid-lowering agents has been shown to protect the testis and reproductive functions $[13,34,46]$. In the present study, the FAS level was significantly greater $(p<0.05)$ in the HC group than in the control group, while the FAS levels did not differ significantly between the HCL group and the control group $(p>0.05)$. The FAS level was significantly negatively correlated with $\mathrm{LH}, \mathrm{FSH}$, and TES levels, while it was significantly positively correlated with TC level.

This study revealed that probiotic treatment is beneficial for reducing the cell degeneration in testicular tissue caused by high cholesterol. Probiotic treatment increased LH, FSH, TSH, and ABP levels, while partially reversing the increase in factor-related apoptosis associated with a high-cholesterol diet. Probiotics have an important role as a supplementary treatment for degeneration and as an adjunct in the treatment of cell structure disorders, although they are not therapeutic in isolation.

\section{Conflict of interest}

No potential conflict of interest relevant to this article was reported. 


\section{Author contributions}

Conceptualization: all authors. Data curation: all authors. Formal analysis: all authors. Methodology: all authors. Project administration: all authors. Visualization: all authors. Writing-original draft: GÇ. Writing-review \& editing: GÇ.

\section{References}

1. Levitan I, Singh DK, Rosenhouse-Dantsker A. Cholesterol binding to ion channels. Front Physiol 2014;5:65.

2. Sulimovici S, Boyd GS. The effect of ascorbic acid in vitro on the rat ovarian cholesterol side chain cleavage enzyme system. Steroids 1968;12:127-49.

3. Chapman MJ, Le Goff W, Guerin M, Kontush A. Cholesteryl ester transfer protein: at the heart of the action of lipid-modulating therapy with statins, fibrates, niacin, and cholesteryl ester transfer protein inhibitors. Eur Heart J 2010;31:149-64.

4. Ashrafi I, Kohram H, Ardabili FF. Antioxidative effects of melatonin on kinetics, microscopic and oxidative parameters of cryopreserved bull spermatozoa. Anim Reprod Sci 2013;139:25-30.

5. Gupta RS, Dixit VP. Effect of dietary cholesterol on spermatogenesis. Z Ernahrungswiss 1988;27:236-43.

6 . Rolfe RD. The role of probiotic cultures in the control of gastrointestinal health. J Nutr 2000;130(2S Suppl):396S-402S.

7. De Boever P, Wouters R, Verschaeve L, Berckmans P, Schoeters G, Verstraete W. Protective effect of the bile salt hydrolase-active Lactobacillus reuteri against bile salt cytotoxicity. Appl Microbiol Biotechnol 2000;53:709-14.

8. Park SC, Hwang MH, Kim YH, Kim JC, Song JC, Lee KW, et al. Comparison of $\mathrm{pH}$ and bile resistance of Lactobacillus acidophilus strains isolated from rat, pig, chicken, and human sources. World J Microbiol Biotechnol 2006;22:35-7.

9. Onody A, Csonka C, Giricz Z, Ferdinandy P. Hyperlipidemia induced by a cholesterol-rich diet leads to enhanced peroxynitrite formation in rat hearts. Cardiovasc Res 2003;58:663-70.

10. Wang L, Zhou B, Zhou X, Wang Y, Wang H, Jia S, et al. Combined lowering effects of rosuvastatin and L. acidophilus on cholesterol levels in rat. J Microbiol Biotechnol 2019;29:473-81.

11. Lim W, Bae H, Sohn JY, Jeong W, Kim SH, Song G. Dietary cholesterol affects expression of prostatic acid phosphatase in reproductive organs of male rats. Biochem Biophys Res Commun 2015;456:421-7.

12. Chen Z, Peng B, Wang S, Peng X. Rapid screening of highly efficient vaccine candidates by immunoproteomics. Proteomics 2004;4:3203-13.

13. Bashandy AE. Effect of fixed oil of nigella sativa on male fertility in normal and hyperlipidemic rats. Int J Pharmacol 2007;3:27-33.

14. Prasad K, Kalra J. Experimental atherosclerosis and oxygen free radicals. Angiology 1989;40:835-43.

15. Kailasapathy K, Chin J. Survival and therapeutic potential of probiotic organisms with reference to Lactobacillus acidophilus and $\mathrm{Bi}-$ fidobacterium spp. Immunol Cell Biol 2000;78:80-8.

16. Huang Y, Wang J, Cheng Y, Zheng Y. The hypocholesterolaemic effects of Lactobacillus acidophilus American type culture collection 4356 in rats are mediated by the down-regulation of Niemann-Pick C1-like 1. Br J Nutr 2010;104:807-12.

17. Tomaro-Duchesneau C, Saha S, Malhotra M, Jones ML, Labbe A, Rodes $L$, et al. Effect of orally administered L. fermentum NCIMB 5221 on markers of metabolic syndrome: an in vivo analysis using ZDF rats. Appl Microbiol Biotechnol 2014;98:115-26.

18. Liu Y, Zhao F, Liu J, Wang H, Han X, Zhang Y, et al. Selection of cholesterol-lowering lactic acid bacteria and its effects on rats fed with high-cholesterol diet. Curr Microbiol 2017;74:623-31.

19. Ejtahed HS, Mohtadi-Nia J, Homayouni-Rad A, Niafar M, Asghari-Jafarabadi M, Mofid V, et al. Effect of probiotic yogurt containing Lactobacillus acidophilus and Bifidobacterium lactis on lipid profile in individuals with type 2 diabetes mellitus. J Dairy Sci 2011;94: 3288-94.

20. Walker DK, Gilliland SE. Relationship among bile tolerance, bile salt deconjugation, and assimilation of cholesterol by Lactobacillus acidophilus. J Dairy Sci 1993;76:956-61.

21. Dambekodi PC, Gilliland SE. Incorporation of cholesterol into the cellular membrane of Bifidobacterium longum. J Dairy Sci 1998; 81:1818-24.

22. Lye HS, Rahmat-Ali GR, Liong MT. Mechanisms of cholesterol removal by lactobacilli under conditions that mimic the human gastrointestinal tract. Int Dairy J 2010;20:169-75.

23. Zhang N, Zhang H, Zhang X, Zhang B, Wang F, Wang C, et al. The relationship between endogenous testosterone and lipid profile in middle-aged and elderly Chinese men. Eur J Endocrinol 2014;170:487-94.

24. Lee CE, Kang JS, Kim KI. Effects of gender, gonadectomy and sex hormones on growth and plasma cholesterol level in rats. Ann Nutr Metab 2008:53:1-5.

25. Hatch NW, Srodulski SJ, Chan HW, Zhang X, Tannock LR, King VL. Endogenous androgen deficiency enhances diet-induced hypercholesterolemia and atherosclerosis in low-density lipoprotein receptor-deficient mice. Gend Med 2012;9:319-28.

26. Hardy MP, Gao HB, Dong Q, Ge R, Wang Q, Chai WR, et al. Stress hormone and male reproductive function. Cell Tissue Res 2005; 322:147-53.

27. Poutahidis T, Springer A, Levkovich T, Qi P, Varian BJ, Lakritz JR, et al. Probiotic microbes sustain youthful serum testosterone levels 
and testicular size in aging mice. PLoS One 2014;9:e84877.

28. Ghoneim MA, Moselhy SS. Antioxidant status and hormonal profile reflected by experimental feeding of probiotics. Toxicol Ind Health 2016:32:741-50.

29. Jones R, Mann T, Sherins R. Peroxidative breakdown of phospholipids in human spermatozoa, spermicidal properties of fatty acid peroxides, and protective action of seminal plasma. Fertil Steril 1979;31:531-7.

30. Padron RS, Mas J, Zamora R, Riverol F, Licea M, Mallea L, et al. Lipids and testicular function. Int Urol Nephrol 1989;21:515-9.

31. Ramírez-Torres MA, Carrera A, Zambrana M. High incidence of hyperestrogenemia and dyslipidemia in a group of infertile men. Ginecol Obstet Mex 2000;68:224-9.

32. Yamamoto Y, Shimamoto K, Sofikitis N, Miyagawa I. Effects of hypercholesterolaemia on Leydig and Sertoli cell secretory function and the overall sperm fertilizing capacity in the rabbit. Hum Reprod 1999;14:1516-21.

33. Tanaka M, Nakaya S, Kumai T, Watanabe M, Matsumoto N, Kobayashi S. Impaired testicular function in rats with diet-induced hypercholesterolemia and/or streptozotocin-induced diabetes mellitus. Endocr Res 2001;27:109-17.

34. Shalaby MA, el-Zorba HY, Kamel GM. Effect of alpha-tocopherol and simvastatin on male fertility in hypercholesterolemic rats. Pharmacol Res 2004;50:137-42.

35. Saez Lancellotti TE, Boarelli PV, Monclus MA, Cabrillana ME, Clementi MA, Espinola LS, et al. Hypercholesterolemia impaired sperm functionality in rabbits. PLoS One 2010;5:e13457.

36. Ibrahim HA, Zhu Y, Wu C, Lu C, Ezekwe MO, Liao SF, et al. Selenium-enriched probiotics improves murine male fertility compromised by high fat diet. Biol Trace Elem Res 2012;147:251-60.

37. Bataineh HN, Nusier MK. Effect of cholesterol diet on reproductive function in male albino rats. Saudi Med J 2005;26:398-404.
38. Kangasniemi M, Kaipia A, Toppari J, Perheentupa A, Huhtaniemi I, Parvinen M. Cellular regulation of follicle-stimulating hormone (FSH) binding in rat seminiferous tubules. J Androl 1990;11:33643.

39. Sluka P, O'Donnell L, Bartles JR, Stanton PG. FSH regulates the formation of adherens junctions and ectoplasmic specialisations between rat Sertoli cells in vitro and in vivo. J Endocrinol 2006;189: 381-95.

40. McLachlan RI, O’Donnell L, Meachem SJ, Stanton PG, De Kretser DM, Pratis K, et al. Hormonal regulation of spermatogenesis in primates and man: insights for development of the male hormonal contraceptive. J Androl 2002;23:149-62.

41. Hammond GL, Underhill DA, Rykse HM, Smith CL. The human sex hormone-binding globulin gene contains exons for androgen-binding protein and two other testicular messenger RNAs. Mol Endocrinol 1989;3:1869-76.

42. Dardmeh F, Alipour H, Gazerani P, van der Horst G, Brandsborg E, Nielsen HI. Lactobacillus rhamnosus PB01 (DSM 14870) supplementation affects markers of sperm kinematic parameters in a diet-induced obesity mice model. PLoS One 2017;12:e0185964.

43. Zarei A, Ashtiyani SC, Vaezi GH. A study on the effects of the hydroalcholic extract of the aerial parts of Alhagi camelorum on prolactin and pituitary-gonadal activity in rats with hypercholesterolemia. Arch Ital Urol Androl 2014;86:188-92.

44. Alzubaidi NA, Al Diwan MA. The effect of taurine on reproductive efficiency in male rats fed high cholesterol diet. Basrah J Vet Res 2013;12:30-40.

45. Zhang K, Lv Z, Jia X, Huang D. Melatonin prevents testicular damage in hyperlipidaemic mice. Andrologia 2012;44:230-6.

46. Fang X, Xu QY, Jia C, Peng YF. Metformin improves epididymal sperm quality and antioxidant function of the testis in diet-induced obesity rats. Zhonghua Nan Ke Xue 2012;18:146-9. 